\title{
Evidence that the mouse insulin receptor substrate-1 belongs to the gene family on which the promoter is activated by estrogen receptor $\alpha$ through its interaction with Sp1
}

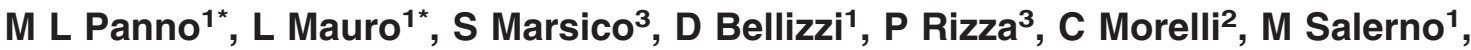 \\ F Giordano ${ }^{1}$ and S Ando'1,2,3
}

${ }^{1}$ Department of Cellular Biology, ${ }^{2}$ Faculty of Pharmacy and ${ }^{3}$ Centro Sanitario, University of Calabria, Via Pietro Bucci, cubo 4c, 87030 Arcavacata di Rende (CS), Italy

(Requests for offprints should be addressed to S Ando' at the Department of Cellular Biology, University of Calabria; Email: sebastiano.ando@unical.it)

*(M L Panno and L Mauro contributed equally to this work)

\begin{abstract}
In the present study, the molecular mechanism underlying the up-regulatory effect of estradiol $\left(\mathrm{E}_{2}\right)$ on mouse insulin receptor substrate-1 (IRS-1) promoter was investigated in $\mathrm{CHO}$ cells on which the same promoter had first been functionally characterized. The mouse IRS-1 promoter bears four consensus half Estrogen Responsive Elements (ERE) sequences and thirteen AP-1- and ten Sp1-binding elements. We performed molecular dissection of this promoter gene providing $3^{\prime}$ different deleted constructs, containing the same AP-1 rich region with a progressively increased number of ERE half sites located downstream. None of these constructs was responsive to $E_{2}$, while a downstream region ( $\mathrm{nt}-1420$ to -160 ) rich in $\mathrm{GC}$ elements was induced by $\mathrm{E}_{2}$. However, the latter region lost its intrinsic $E_{2}$ responsiveness when the whole IRS-1 promoter was mutated for deletion in all four ERE half sites. Deletion analysis of the ERE half sites demonstrated that only ERE located at the position -1500 to -1495 , close to the GC-rich region, was able to maintain the induced activatory effect of $E_{2}$ on the IRS-1 gene. Electrophoretic mobility shift and chromatin immunoprecipitation assays identified the region containing the half ERE/Sp1 ( $\mathrm{nt}-1500$ to -1477 ) as the one conferring $E_{2}$ responsiveness to the whole promoter. This effect occurs through the functional interaction between $\mathrm{E}_{2} / \mathrm{ER} \alpha$ and Sp1.
\end{abstract}

Journal of Molecular Endocrinology (2006) 36, 91-105

\section{Introduction}

Estrogen and insulin-like growth factor (IGF) regulate breast cancer cell growth and survival through the activation of distinct transductional pathways (Dickson \& Lippman 1987, 1995, Surmacz 2000). However, evidence of a cross-talk between estrogen and growth factors (such as IGFs) has been documented, addressing an additive effect of these two mitogenic systems on breast cancer cell growth and survival (Molloy et al. 2000, Yee \& Lee 2000).

The previous findings of ourselves and others have disclosed novel arguments to sustain the cross-talk between the two signals, demonstrating how exposure of breast cancer cells to estradiol $\left(\mathrm{E}_{2}\right)$ enhances the expression of insulin receptor substrate-1 (IRS-1), a key molecule linked to phosphatidylinositol-3 kinase (PI3K)/Akt and ERK1/ERK2 pathways, crucial for cell proliferative response and survival (Surmacz 2000, Molloy et al. 2000, Yee \& Lee 2000, Mauro et al. 2001). This deduction fits well with previous evidence reporting on how the mitogenic effects of insulin or IGF-I were amplified by exposure to estrogen (Ando' et al. 1998, Lee et al. 1999). In addition, breast cancer cells overexpressing IRS-1 show a marked growth advantage and reduced or abrogated estrogen growth requirements (Guvakova \& Surmacz 1997). Our recent data have demonstrated that $\mathrm{E}_{2}$ is able to increase IRS-1 mRNA level through activation of the regulatory region of the IRS-1 gene (Mauro et al. 2001). Mouse IRS-1 promoter, characterized for the first time by Araki et al. (1995) in CHO cells, has furthermore been analyzed and our results show four consensus half Estrogen Responsive Elements (ERE) sequences and thirteen AP-1- and ten Spl-binding elements. These might be important regulatory sites for the actions of estrogen. The up-regulatory effect induced by $\mathrm{E}_{2}$ on this promoter activity in both MCF-7 and CHO cells, expressing estrogen receptor $\alpha(\mathrm{ER} \alpha)$, seems to underscore a general mechanism which is not strictly related to the cell type (Mauro et al. 2001).

In the present study, we have demonstrated, through a molecular dissection of the IRS-1 promoter, how the region bearing the ERE half site, separated by 12 
nucleotides from the Spl site $\left(5^{\prime}\right.$-AGGTCA(N) ${ }_{12} \mathrm{CGG}$ CGC-3') within nt -1500 to -1477 , is responsible for the $\mathrm{E}_{2}$-induced activation of the whole IRS-1 promoter. Both electrophoretic mobility shift assay (EMSA) and chromatin immunoprecipitation (GhIP) assay confirmed that the above-mentioned sequence is functionally involved in mediating the up-regulatory effect induced by $\mathrm{E}_{2}$ on IRS-1 expression. The effect, as documented for other $\mathrm{E}_{2}$-responsive genes, occurs through the interaction between $\mathrm{ER} \alpha$ and $\mathrm{Spl}$ proteins, bound separately to the ERE half sequence and $\mathrm{Spl}$ responsive element respectively and present in the ERE/Spl region of the IRS-1 promoter (Dubik \& Shiu 1992, Wu-Peng et al. 1992, Krishnan et al. 1994, Rishi et al. 1995, Porter et al. 1996, 1997, Scholz et al. 1998, Petz \& Nardulli 2000, Saville et al. 2000, Khan et al. 2003).

\section{Materials and methods}

\section{Materials}

Dulbecco's modified essential medium (DMEM)/Ham's F-12, L-glutamine, penicillin/streptomycin, calf serum (CS), bovine serum albumin (BSA), aprotinin, leupeptin, phenylmethylsulfonyl fluoride (PMSF), sodium orthovanadate, 4-OH-tamoxifen and $\mathrm{E}_{2}$ were purchased from Sigma (Milan, Italy). FuGENE 6 and poly (dI-dG) were from Roche Applied Science (Milan, Italy). Taq DNA polymerase, T4 polynucleotide kinase, $1 \mathrm{~kb}$ DNA ladder, dual luciferase kit, $\mathrm{pGL}_{2}$ basic vector and timidine kinase promoter (TK) Renilla luciferase plasmid were provided by Promega (Madison, WI, USA). $\left[\gamma^{32} \mathrm{P}\right]$ ATP, Sephadex G50 spin columns and the enhanced chemoluminescence (ECL) system were from Amersham Biosciences. Spl (1C6), ER $\alpha$ F10 and $\beta$-actin antibodies were purchased from Santa Cruz Biotechnology (Santa Cruz, CA, USA). IRS-1 antibody was from UpState Biotechnology (New York, NY, USA). Human recombinant $\mathrm{ER} \alpha$ and $\mathrm{Sp} 1$ proteins were obtained from Invitrogen (Carlsbad, CA, USA) and Alexis (Lausen, Switzerland) respectively.

The plasmid pBluescript SKII containing mouse IRS- 1 promoter $(3.3 \mathrm{~kb})$ and a codifying region of the IRS-1 gene $(3 \cdot 4 \mathrm{~kb})$ was kindly given by Dr Kaku Tsuruzoe (Research Division, Joslin Diabetes, Boston, MA, USA). pHEGO plasmid, containing the full length of ER $\alpha$ cDNA was generously provided by Dr Didier Picard (Department of Cellular Biology, University of Geneva, Geneva, Switzerland).

\section{Plasmids}

The sequence of the IRS-1 mouse promoter was analyzed by MatInspector V2.2 software to identify potential transcriptional regulatory sites, such as AP-1, Spl and ERE, other than that characterized by Araki et al. (1995). The MatInspector V2.2 software is available at the web url http://transfac.gbf.de/cgi-bin/ matSearch/matsearch.pl; it allows the identification of consensus sequences of transcriptional factors through the TRANSFAC data base (http://transfact.gbf.de/ TRANSFAC/) (Quandt et al.1995).

Plasmid pIRS-1-luciferase (luc) was generated by inserting the $3.3 \mathrm{~kb}$ fragment of the mouse IRS-1 gene promoter into the $\mathrm{pGL}_{2}$ expression vector containing a luciferase gene. The sequence was confirmed by automated sequencing analysis with a BigDye terminator cycle sequencing ready reaction kit (Applied Biosystems, Foster City, CA, USA).

IRS-1 promoter fragments (pIRS-1A-luc, pIRS-1Bluc, pIRS-1C-luc) were synthesized by unidirectional deletion using the esonuclease III reaction (Ausubel $e t a l$. 1988). pIRS-1D-luc was obtained by PGR using 5'-CGG TCGCTCACTCGTGCGT-3' and 5'-GGAAGATAG CGTGATCGGAG-3' as the sense and antisense primers respectively.

All ligation products were transformed into competent Escherichia coli cells (Invitrogen). Plasmids were isolated, and clones were confirmed by DNA sequencing. pHEGO plasmid contains the full-length ER $\alpha$ cDNA. The Renilla luciferase reporter vector pRL-TK (Promega) was used as a transfection standard to normalize transfection efficiency.

\section{PCR mutagenesis}

The plasmids pEREmut-luc, pERE1,2,3,mut-luc and pERE4 mut-luc were generated by PCR mutagenesis (Clackson et al. 1991).

pEREmut-luc contained mutation of all ERE half sites, located at sites nt -2218 to $-2213,-2128$ to $-2123,-2050$ to -2045 and -1500 to -1495 . To generate this plasmid, PCRs were performed using the primers 1s (3'-GGCACCTCAGAGCAGATGG-5') and 2a (5'-TGGGGGCGGTGGGGGGGAGGGGACGAC CGAACAGGTAAAGGCGACCCCGG-3') to obtain the amplified product A (nt -3350 to -2240 ); the non-mutagenic external primer 3s (3'-CGTCTAATGC TCGTGCAAAC-5 ${ }^{\prime}$ ) and the mutagenic internal primer 6a (5'-TGGGGGCGCTGGGGCGGAGGGGACGAC CCAACAGGTAAAGGCGACGCGCG-3') to obtain the amplified product $\mathrm{B}$ (nt -2026 to -1466 ); the mutagenic internal primer $5 \mathrm{~s}$ ( $5^{\prime}$-CGGGGGTCGCGT TTACGTGTTGGGTCGTCACGTCGGCGCGAGC GCGCCCA-3') and the non-mutagenic external primer 4a (3'-AGGAAGATAGCATGATCGGA-5') to obtain the amplified product $\mathrm{C}$ (nt -1536 to -170$)$. Products $\mathrm{B}$ and $\mathrm{C}$ were used as templates in a second PCR using the primers $3 \mathrm{~s}$ and $4 \mathrm{a}$ (product $\mathrm{D}$, nt -2026 to -170 ). Products A and D were restricted by BamHI (specific sites were present in primers $2 \mathrm{a}$ and $3 \mathrm{~s}$ ) and ligated to obtain product E, lacking all ERE half sites, which was further 
digested by SacI and HindIII (specific sites were present in primers $1 \mathrm{~s}$ and $4 \mathrm{a}$ ) and inserted in the $\mathrm{pGL}_{2}$ plasmid.

pERE1,2,3,mut-luc contained mutations of the three ERE half sites, located at the sites nt -2218 to -2213 , -2128 to -2123 and -2050 to -2045 , and was generated using product $\mathrm{A}$, as described above, and product $\mathrm{F}$ (nt -2026 to -170 ) obtained by PCR using primers $3 \mathrm{~s}$ and $4 \mathrm{a}$. Products $\mathrm{A}$ and $\mathrm{F}$ were restricted by BamHI, ligated to obtain product $G$, lacking the three ERE half sites, which was further digested by SacI and HindIII and inserted in the $\mathrm{pGL}_{2}$ plasmid.

pERE4 mut-luc was mutated in the ERE half sites corresponding to nt -1500 to -1495 , and was constructed using product $\mathrm{C}$, as described above, and product $\mathrm{H}$ (nt -3350 to -1466 ) obtained by PCR using the primers $1 \mathrm{~s}$ and $6 \mathrm{a}$. Products $\mathrm{C}$ and $\mathrm{H}$ were used as templates in a second PCR using the primers $1 \mathrm{~s}$ and $4 \mathrm{a}$ to obtain product $\mathrm{L}$. The latter product was digested by SacI and HindIII and inserted in the $\mathrm{pGL}_{2}$ plasmid.

Point mutations were done by PCR-mediated site-specific mutagenesis using degenerate primers, replacing one $\mathrm{G}$ with $\mathrm{T}$ in the ERE sequences. Namely, the ERE half site was located at position nt -2218 to - 2213: AGtTCA; the ERE half site was located at position nt -2128 to -2123 : TtACGC; the ERE half site was located at position nt -2050 to -2045 : TCAAtG; the ERE half site was located at position nt - 1500 to - 1495: AGtTCA (mutations are shown as lower case letters).

\section{Cell lines and culture conditions}

CHO cells were obtained from the American Type Culture Collection (Manassas, VA, USA). Wild-type human breast cancer (MCF-7) cells were a gift from Dr E Surmacz (Kimmel Cancer Institute, Philadelphia, PA, USA).The cell lines were cultured in DMEM/ Ham's F12 (1:1) medium supplemented with 5\% CS, $1 \%$ L-glutamine and $1 \%$ penicillin/streptomycin. The cells were cultured in phenol red-free, serum free medium, DMEM (PRF-SFM-DMEM) containing 0.5\% BSA, $1 \%$ L-glutamine and $1 \%$ penicillin/streptomycin, $24 \mathrm{~h}$ before each experiment.

\section{Transfections and luciferase assay}

CHO and MCF-7 cells were seeded $\left(1 \times 10^{5}\right.$ cells/well $)$ in DMEM/F-12 supplemented with 5\% CS in 24-well plates. CHO cells were cotransfected with pIRS-1-luc promoter construct and pHEGO. Cells were transfected in SFM using FuGENE6 according to the manufacturer's instructions with a mixture containing $1 \mu \mathrm{g} /$ well of each specific plasmid and $25 \mathrm{ng} /$ well of TK Renilla luciferase plasmid. An empty $\mathrm{pGL}_{2}$ vector was used as the control vector to measure basal activity. Twenty-four hours after the transfection the medium was changed and the cells were treated in PRF-SFM-DMEM in the presence of $10 \mathrm{pM}$ and 1,10 and $100 \mathrm{nM} \mathrm{E}$. The firefly and Renilla luciferase activities were measured by using a dual luciferase kit. The firefly luciferase data for each sample were normalized on the basis of the transfection efficiency measured by Renilla luciferase activity.

\section{Western blotting}

$\mathrm{CHO}$ and MCF-7 cells were grown in $100 \mathrm{~mm}$ dishes to 70-80\% confluence, shifted to SFM for $24 \mathrm{~h}$ and lysed. Protein lysates were obtained with a buffer containing $50 \mathrm{mM}$ HEPES, pH $7.5,150 \mathrm{mM} \mathrm{NaCl}, 1.5 \mathrm{mM}$ $\mathrm{MgCl}_{2}, 10 \mathrm{mM}$ EGTA, pH 7.5, 10\% glycerol, $1 \%$ Triton X-100 and protease inhibitors $\left(2 \mu \mathrm{M} \mathrm{Na} \mathrm{No}_{4}\right.$, $1 \% \mathrm{PMSF}$ and $20 \mu \mathrm{g} / \mathrm{ml}$ aprotinin).

The expression of IRS-1 was tested by Western blotting in $50 \mu \mathrm{g}$ protein lysates using an anti-IRS-1 antibody. Proteins were separated by SDS-PAGE and then transferred to a nitrocellulose membrane, probed with primary antibody and then stripped and reprobed with $\beta$-actin antibody. The antigen-antibody complex was detected by incubation of the membranes for $1 \mathrm{~h}$ at room temperature with a peroxidase-coupled anti-IgG antibody and revealed using the ECL system. Blots were then exposed to film and bands were quantified by densitometer. The results obtained are expressed in terms of arbitrary densitometric units.

\section{Gel mobility shift assay}

Nuclear extracts were prepared from CHO cells as previously described (Andrews \& Faller 1991). The probe was generated by annealing single stranded oligonucleotides and labeled with $\left[\gamma^{32} \mathrm{P}\right] \mathrm{ATP}$ and T4 polynucleotide kinase, and then purified using Sephadex G50 spin columns. The DNA sequences used as probe or as cold competitors were as follows (the nucleotide motifs of interest are underlined, mutations are shown as lower case letters): Spl 5'-GTTGGGACTTGGCAGCt CGCGTCCCCCTGCCGAAG-3'; ERE/Spl 5'-GAG AGCTAGCAGtTCACGCGCGTCGCGTCtGCGCGA GCGCCGCGACCCTC-3'. The DNA sequence used as

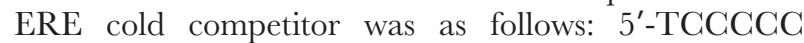
TGCAAGGTCACGGTGGCGACGCGGTG-3'. Oligonucleotides were synthesized by MWGBiotech (Ebersberg, Germany). The protein binding reactions were carried out in $20 \mu \mathrm{l}$ buffer $(20 \mathrm{mM}$ HEPES, $\mathrm{pH} 8,1 \mathrm{mM}$ EDTA, $50 \mathrm{mM} \mathrm{KCl}, 10 \mathrm{mM}$ dithiothreitol (DTT), 10\% glycerol, $1 \mathrm{mg} / \mathrm{ml} \mathrm{BSA}, 50 \mu \mathrm{g} / \mathrm{ml}$ poly $(\mathrm{dI}-\mathrm{dC})$ ) with 50000 c.p.m. labeled probe, $20 \mu \mathrm{g}$ CHO nuclear protein or an appropriate amount of ER $\alpha$ or Spl human recombinant proteins, and $5 \mu \mathrm{g}$ poly $(\mathrm{dI}-\mathrm{dG})$. The mixtures were incubated at room temperature for $20 \mathrm{~min}$ in the presence or absence of unlabeled 
competitor oligonucleotides. The specificity of the binding was tested by adding specific antibodies (anti-ER $\alpha$ and anti-Spl) to the reaction mixture. The entire reaction mixture was electrophoresed through a $4 \%$ polyacrylamide gel in $0.25 \times$ Tris borate-EDTA for $3 \mathrm{~h}$ at $150 \mathrm{~V}$. The gel was dried and subjected to autoradiography at $-70^{\circ} \mathrm{C}$.

\section{ChIP and Reverse (Re)-ChIP assays}

We followed the ChIP methodology described by Morelli et al. (2004). CHO cells were transiently transfected with pHEGO plasmid and treated with $100 \mathrm{nM} \mathrm{E}_{2}$ for $1 \mathrm{~h}$, or left untreated in SFM. The cells were then cross-linked with $1 \%$ formaldehyde and sonicated. Supernatants were immunocleared with sonicated salmon DNA/protein A agarose (Upstate Biotechnology Inc., New York, NY, USA) and immunoprecipitated with anti-ER $\alpha$ antibody $(\mathrm{Ab}) \mathrm{F}-10$ (Santa Cruz Biotechnology). Pellets were washed as reported in Morelli et al. (2004), eluted with elution buffer $\left(1 \%\right.$ SDS and $\left.0 \cdot 1 \mathrm{M} \mathrm{NaHCO}-{ }_{3}\right)$ and digested with proteinase $\mathrm{K}$ (Morelli et al. 2004). DNA was obtained by phenol/chloroform extractions and precipitated with EtOH. PGR was carried out with the ERE/Spl primers: upstream 5'-CTCACGGAGACAC CGACATC-3' and downstream 5'-ACGCGCGTGC CACGCAGAGC-3', or with the primers amplifying the IRS-1 promoter region containing the three upstream and non-functional ERE half sequences: upstream 5'-CAGGGAGTCTAGTGGATTGA-3' and downstream 5'-TGTGTATATGTTAGGAGATGTTTG-3'.

In Re-ChIP experiments, complexes from ERa immunoprecipitations (IPs) were eluted in RE-ChIP buffer (0.5 mM DTT, $1 \%$ Triton X-100, 2 mM EDTA, $150 \mathrm{mM} \mathrm{NaCl}$ and $20 \mathrm{mM}$ Tris-HCl, $\mathrm{pH} 8 \cdot 1$ ) and subjected again to the ChIP procedure by using anti-Sp1 antibody PEP2 (Santa Cruz Biotechnology). Inputs were used as loading control and were obtained by eluting DNA from $5 \mu$ cell lysates prior to the IP step. Negative control was performed using normal IgGs in place of the primary antibody.

\section{Statistical analysis}

Each data point represents the means \pm S.D. of at least three experiments. The data were analyzed by ANOVA using the STATPAC computer program (Statpac Inc., Bloomington, MN, USA).

\section{Results}

\section{Analysis of the IRS-1 mouse promoter sequence}

Sequencing of the IRS-1 mouse promoter by MatInspector V2.2 software (see Materials and methods) led us to the identification of new potential transcriptional regulatory sites, in addition to those characterized by Araki et al. (1995), namely thirteen AP-1, ten Spl and four ERE half sites (Fig. 1). All these sites could be potential targets of $\mathrm{E}_{2}$ action resulting in the activation of the IRS-1 promoter.

\section{Identification of an $\mathrm{E}_{2}$-activated IRS-1 promoter region}

In $\mathrm{CHO}$ cells transiently co-transfected with pHEGO and pIRS-1-luc, encoding the full length of IRS-1 gene promoter linked to the firefly luciferase reporter gene, $\mathrm{E}_{2}(10 \mathrm{pM}$ and 1,10 and $100 \mathrm{nM})$ was able to induce luciferase activity (Fig. 2A). The same results were obtained in ER-positive human breast cancer MCF-7 cells transfected with pIRS-1-luc (Fig. 2B). $\mathrm{E}_{2}$ up-regulated IRS-1 protein content in both $\mathrm{CHO}$ and MCF-7 cells in a dose-dependent manner (Fig. 3).

Previous findings have demonstrated that ER may indirectly modulate transcription by interaction with the AP-1 sites (Umayahara et al. 1994, Paech et al. 1997, Webb et al. 1999); thus, we checked the potential role of the AP-1-rich region in mediating the activatory effect induced by $\mathrm{E}_{2}$ on the IRS-1 promoter. In the same vein, we checked how the four ERE half sites may work, together with AP-1, in mediating the up-regulatory effect of $\mathrm{E}_{2}$ on the activity of the whole IRS-1 promoter. With this aim, we transiently co-transfected CHO cells with pHEGO and three different $3^{\prime}$-deleted constructs conjugated with a luciferase reporter gene containing the same AP-1-rich region with a progressively increased number of ERE half sites, namely: (i) pIRS-1A-luc, containing one ERE half site (nt -3370 to -2180 ), (ii) pIRS-1B-luc, containing three ERE half sites (nt -3370 to - 1650) and (iii) pIRS-1C-luc, containing four ERE half sites (nt -3370 to -1308). None of these constructs was stimulated by $\mathrm{E}_{2}$ (Fig. 4).

On the contrary, the plasmid pIRS-1D-luc, containing the residual downstream region (nt -1420 to -160), rich in GC elements, was responsive to $E_{2}$ action (Fig. 4). The potential positive influence of AP-1 sites in the construct rich in Spl sequences has been ruled out since in previous experiments the deletion of the AP-1 site in the construct pIRS-1D-luc did not elicit substantial effects in the $\mathrm{E}_{2}$-responsiveness (data not shown). Earlier reports (Saville et al. 2000) have shown how $\mathrm{Spl}$ cis-elements located in the promoter region of some genes are responsive to $\mathrm{E}_{2}$; we therefore ascertained if the IRS-1 CG-rich region, present in the full length of IRS-1 promoter, was able to yield estrogen responsiveness independently on the four ERE half sites. Consequently, we performed site-specific mutagenesis at the ERE half sites of the IRS-1 mouse promoter located upstream to the CG-rich region. The effects of the site-specific mutagenesis on basal activity and $\mathrm{E}_{2}$ 
-3370 ggatccaatc cagggccttg gcacctcaga gcagatggtc tacttcttct tcagtcagaa -3310 taacattact tttatatcat aacacccta atgttctgtg aagatgactt ataaaatct -3250 tccaaattaa attgtttttt ttgttgtctc ctccttcaag aaaatacttt cctccataaa -3190 ggtacctcct ttttcccct ctctcttttt tgtttgttct tggttggtga cagaggtcag -3130 gaaggaagta attttaaaag ttaaagtctg gatttgaagt gctttcctac ataatgcgag -3070 gtcccctccc tgtggactaa tctagattaa gcagttgcta gactagacta gctgtttatt -3010 cccccccce ccccacacac acactgttat tctgctacac taacttcaga tatctctagt -2950 tgctatcctc ccaaccceta atgcatttca aatctttaga gtcctcttct tgctattgca -2890 gtctccgtac cttttccaaa ttacttgcta tttatagcct tcctgtagtg ggcacatgtg -2830 cccgcatcac caagctgtca gaggggaaaa atgaaggcta tcaattcaat gtgtaccgca -2770 taatccatta accaggttta ggagaaactg catgataaag gaggtgaaaa gagaaacag -2710 aggctcctga getttcgaga ggaggtgaca cctacagatg cggaataccc caattcaagt -2650 accgcaagca tctgaatggc gccagtgcct acatctgtac cctctccctc tctcccettt -2590 accgcatctg tgcaagacag gaaagacagg caactccacc aatcagcagg ctgccccagg -2530 aacctcadcc cgcc|tctcta gccgcattat getgaggcgc gcagccccet ttaccitcc -2470 gctcctcccc tactccaagc caggcagtct agtggattga gcatgcccag caccttact -2410 gctgcgtctc actgcaaaca acctgcagtg ctggagagcg ggaggctgag agggttcctg -2350 gettaggaaa agaggtggaa aactagaa cc gccCatgget agagtagaat ggctttaagc -2290 actgggagca acgtcacatt tgtaggtctt taatgccggt tgggctagac agggacaccc -2230 tgcttgattt ataggtcatc ttaaaaagaa aaagaaaaa aaaactttg gggagcgtct ERE:

-2170 gcttgtggtg agactaagaa ataggctttg caaagaggct gctgacccgt tttcatcaag ERE

-2110 aagtacccat tttcctgtgc agcctagcca cttatccttg tctcccactt atccttgtgg

-2050 tcaaggttaa aagtgtatag ggtcgtctaa tgctcgtgca aactatgaaa caaacatctg ERE

-1990 ctaacatata cacagtaagg gtgtacactt aggaactctc tgaaggtcct ttacatcttt -1930 aaaaaaatc acaaatagac ttacgaatgt gataaggggt gccaggtttc ctccagcccc -1870 cgccccccac cttttgcact aactaaccet taagtgtgaa tccctcttca cctgcatgaa -1810 ggaagagaaa tggtgacttt tacattttat ttccttagtg atcagcggct aatagtgcca -1750 ggtgtgagat cccaggtcgc gattccgaga gaccctaacc tagccaacag tcattgccet -1690 tgggcgtccc tctctgtttc ttccaggtgc ttcaccacgg tacgtccgga gattccaggt -1630 ggaagactgg ctcagaagtc ctttagaaaa tcttacaaaa atgtagatct ccctaccagg -1570 gcctctcacc cagacaccga catccagctg cctcccgggg gtcgccttta cetgttgggt -1510 gagagctagc aggtcacceg cgtccectcc gccesagcgc ccccaccetc toggggetct ERE

-1450 gcagccgcag tgcaccccce ctctcactgc cccctccctc actcctgcgt cttccccaga -1390 tcccccctc ccgttttccc agactcccet cetgctttgc ggtagccacc caaacaagcc -1330 tgcectcceg cogegggatt cetacgggcc gggggcgctc tgggtggcac gggegtggga

-1270 gacacagcgc cccgggctct gcggccacgc agggcgetgc cgagcgtgca gcaaagggce -1210 agcgcgcgcg ctctgcggca cggccagggg gtggagaggg gcgggcgtog ggcgggctcg -1150 ggccggaatg tagagcgagc agggagaggg agagagaccc gggctggacc gtcccggcgg -1090 cggccaggct getgagcgca gaggctccqt cacgtgtttt gctcctctgg agtgagacgg -1030 cggcgeggtc tgaagagggc cagcgegegg tgccagccgc cgcagccgcc gettgttttg -970 gttggggctc tcggcaactc tccgaggagg aggaaggagg agggaggagg aggagggagg -910 agaaggaggg aggaggagag aagtaactgc agcggctgcg cctcgggagg accgggcgtc -850 ttccccgatc tcttcccaaa cctcccccgc tocccgcctc cctccetcgt cccetcccet -790 cetccettgc ggactggagc taggggcagg gatgagcetg tccetctgga ccgtcccetg -730 ctcccccagc tgcccagtag cgttgcgegt ggaaaagcca ctttcolccgc cogccgagat -670 gggctcgagt gcgggctgca gaggacgcgt cetcgggcgg cagcagcagc agcagcagca -610 gcaacagccg cagcgccgcg gtctctgcga ttgagctggt atttgggcgg ctggtggcga -550 cggggacggt tgaagggtgg gaggaggcag aggaggagga ggagaaggag gagggagaac -490 ccggtgcaac gttgggactt ggcageccgc ctccccetgc ccaaggatat ttaatttgcc -430 tcgggaatcg ctacttccag aggggaactc gggagggaag gcgcgcgcgc ctagagagcc -370 aagcggggac tcctcgggcc atcgctgcct ccctacatcg gactcgacca glggogg -310 gggatgcacc atagctcctt ctctgctgca gggactgggg gagacatagt cetcggaaga -250 ttgcggctgc actcacccta gacccactgc ccttccetct ggcatgaaac gccettaaac -190 tcggatcagg ctatcttcct tggcgcagtt acctcgtcct tcggctgcce ctcccagct -130 ccaggaacag cgtgaatttt ggagtcagaa tttctgcgag cttcctccag cccggagtgc -70 atgtgcgggg ccgcactgag aagccacccc tcacccagtt tttcaacacc tccctctgct

-10 ccgcagcagc

Figure 1 Regulatory sites of the IRS-1 mouse promoter. The analysis of the IRS-1 mouse promoter sequence by MatInspector V2.2 software allowed identification of 13 AP-1 (underlined nucleotides), ten Sp1 (nucleotides in the boxes) and four half ERE (nucleotides in grey boxes) potential regulatory sites. 


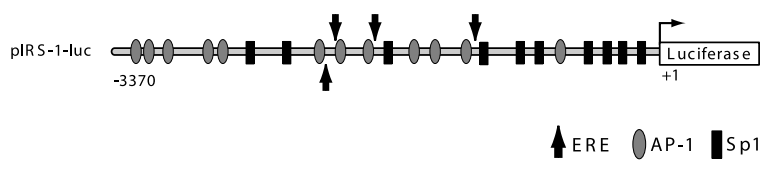

A

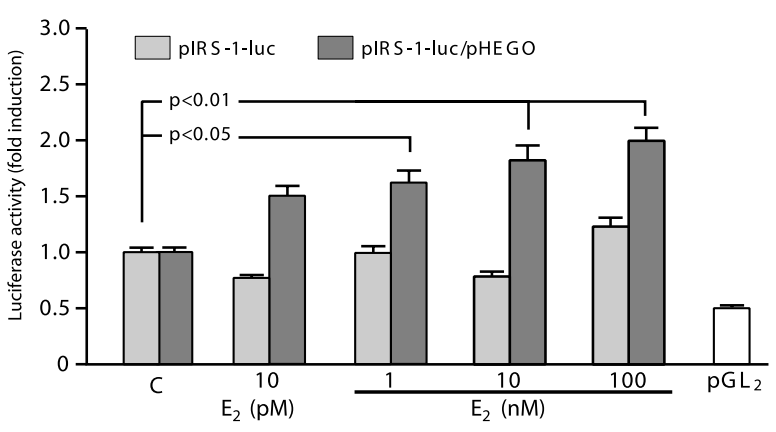

B

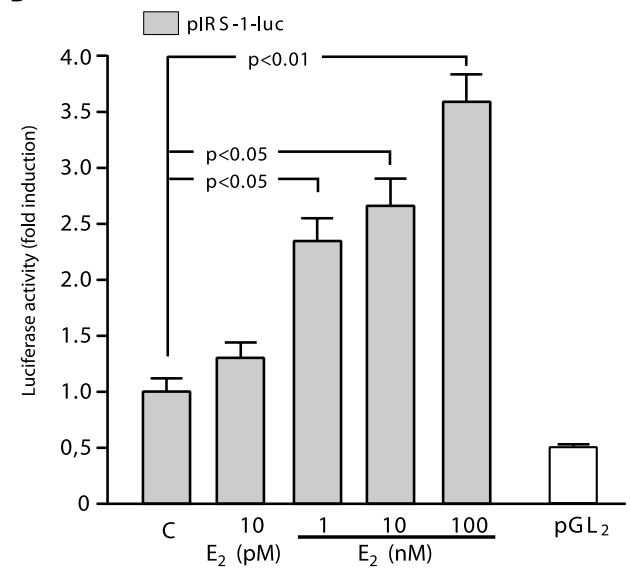

Figure $2 \mathrm{E}_{2}$ enhances IRS-1 promoter activity. (A) CHO cells were co-transfected with pIRS-1-luc and pHEGO together with pRL-TK. (B) MCF-7 cells were transiently transfected with DNA mixture containing pIRS-1-luc and pRL-TK. The transfectants were treated in the absence $(\mathrm{C}$, control) or in the presence of $10 \mathrm{pM}$ and 1,10 and $100 \mathrm{nM} \mathrm{E}_{2}$ for $24 \mathrm{~h}$. These results represent the means \pm S.D. of five different experiments. In each experiment, the activities of the transfected plasmids were assayed in triplicate transfections. $\mathrm{pGL}_{2}$ basal activity was measured in cells transfected with $\mathrm{pGL}_{2}$ basal vector. The firefly luciferase data for each sample were normalized on the basis of the transfection efficiency measured by Renilla luciferase activity.

responsivness were determined in transient transfection studies using the plasmids pEREmut-luc, pERE4 mut-luc and pERE1,2,3 mut-luc (see Materials and methods) (Fig. 5A).

Using the IRS-1 promoter mutated for delection of all four ERE half sites, the CG-rich region, present in the full length of the IRS-1, was unable per se to yield $\mathrm{E}_{2}$ responsiveness. On the contrary, only the ERE half site localized at the position nt -1500 to -1495 , close to the Spl elements, was crucial in maintaining the $E_{2}$
A $\mathrm{E}_{2}$

IRS-1

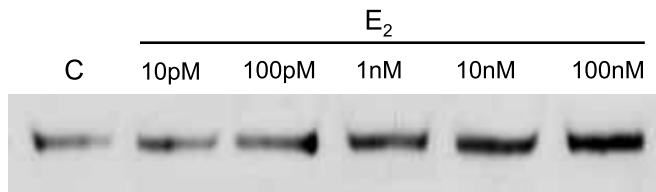

$\beta$-actin

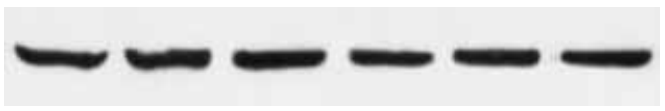

B

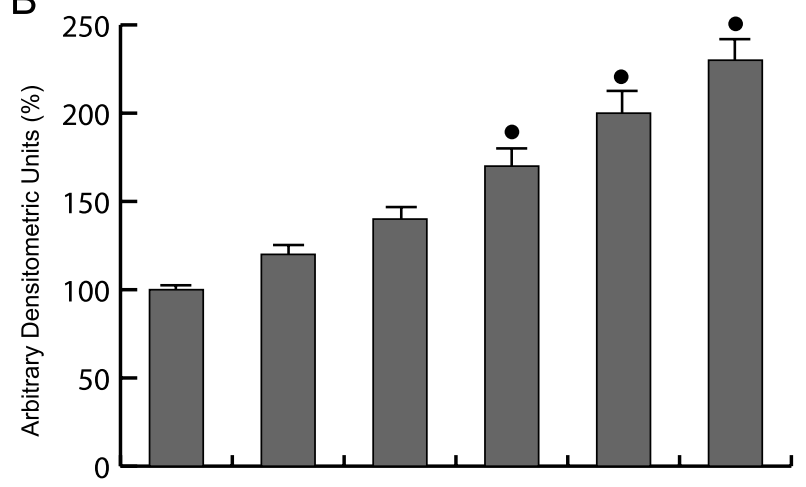

C
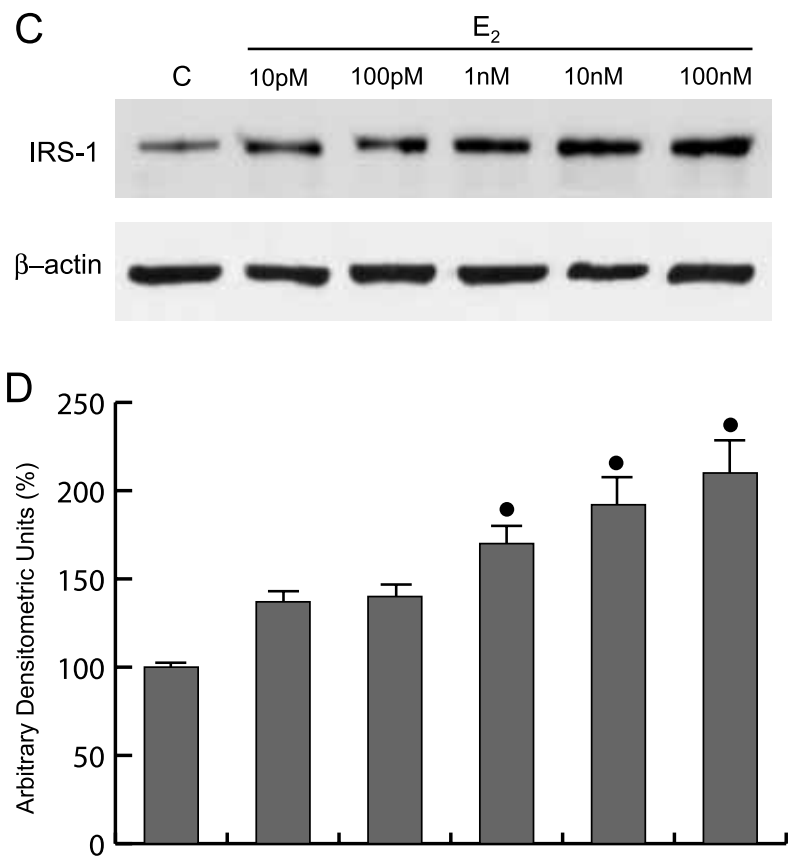

Figure $3 \mathrm{E}_{2}$ up-regulates IRS-1 protein expression. Protein expression of IRS-1 in (A) $\mathrm{CHO}$ and (C) MCF-7 cells treated in the presence or absence of 10 and $100 \mathrm{pM}$ and 1,10 and $100 \mathrm{nM} \mathrm{E}_{2}$ for $24 \mathrm{~h}$. $\beta$-actin served as loading control.

Representative results are shown. The histograms represent the means \pm S.D. of three separate experiments performed in $(B)$ $\mathrm{CHO}$ and (D) MCF-7 cells, in which the band intensities were evaluated in terms of arbitrary densitometric units and expressed as the percentage of the control assumed as $100 \%$. - $P<0.01$ vs control. 

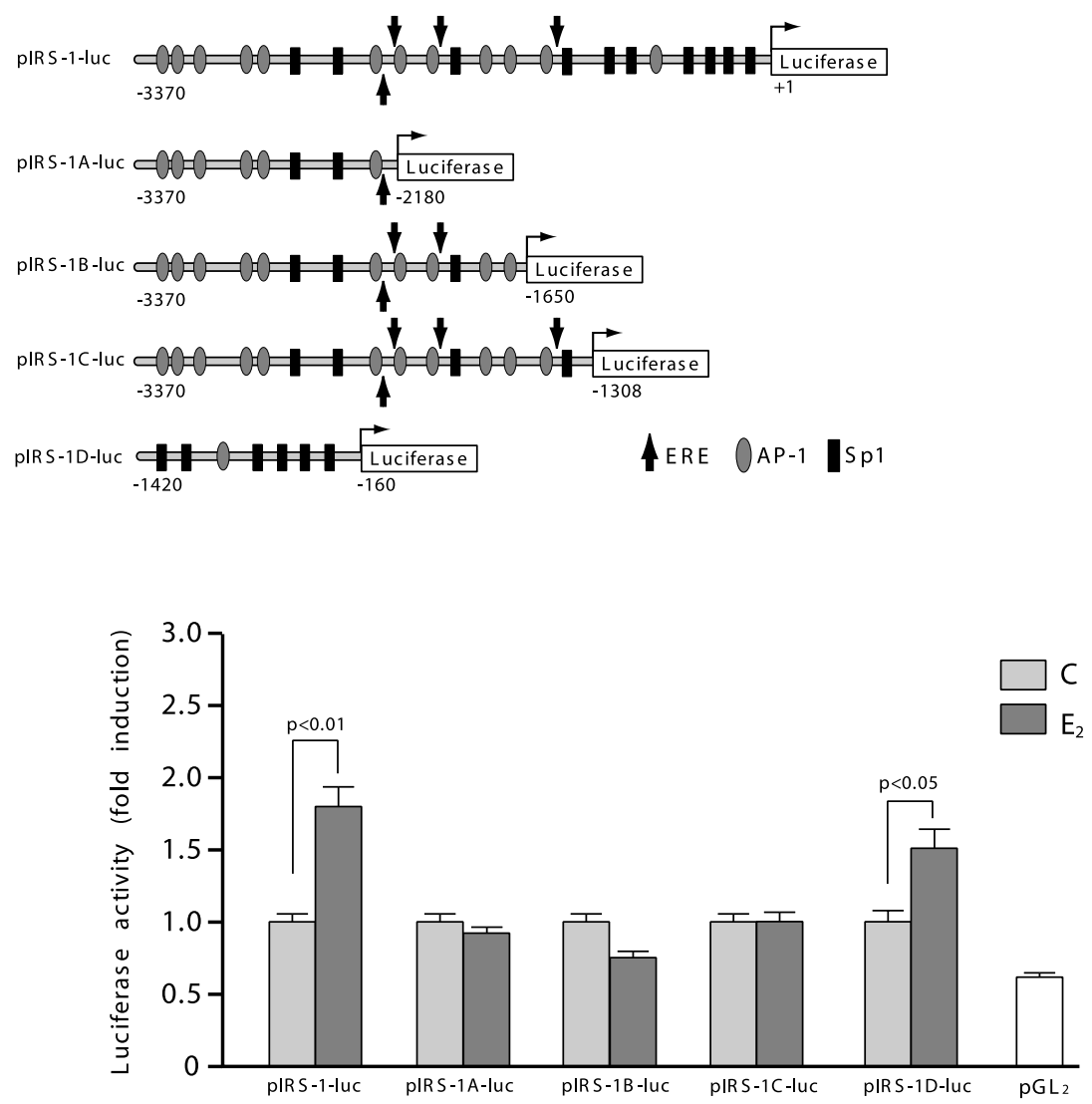

Figure $4 \mathrm{E}_{2}$ responsiveness of different IRS-1 promoter constructs. Transcriptional activity of $\mathrm{CHO}$ cells co-transfected with pHEGO and with different IRS-1 promoter luciferase reporter constructs are shown. $\mathrm{CHO}$ cells were transiently transfected with pIRS-1A-luc, pIRS-1B-luc, pIRS-1C-luc 3'-deleted constructs and pIRS-1D-luc (see Materials and methods) together with pRL-TK. Cells were treated in the absence (C, control) or in the presence of $10 \mathrm{nM} \mathrm{E}_{2}$ for $24 \mathrm{~h}$. These results represent the means \pm S.D. of five different experiments. In each experiment, the activities of the transfected plasmids were assayed in triplicate transfections. $\mathrm{PGL}_{2}$ basal activity was measured in cells transfected with $\mathrm{pGL}_{2}$ basal vector. The firefly luciferase data for each sample were normalized on the basis of the transfection efficiency measured by Renilla luciferase activity.

transactivation of the IRS-1 promoter. Similar results were obtained by performing point mutations in ERE half sequences (data not shown). The important role of the fourth ERE half site together with the $\mathrm{Sp} 1$ region in conferring $\mathrm{E}_{2}$ responsiveness was confirmed by a functional study performed with the following construct bearing: (i) the whole IRS-1 promoter, (ii) the fragment containing the first three ERE half sites and (iii) the fragment containing the fourth ERE half site close to the Spl elements (Fig. 5B). The results showed that pERE4/Sp1-luc, transfected in CHO cells, reproduced the $\mathrm{E}_{2}$ responsiveness pattern similar to the full length of IRS-1 promoter (Fig. 5B).

On the basis of these findings, our attention was focused on the sequence ERE/Spl assumed to be a putative regulatory region target of $\mathrm{E}_{2}$ action.

\section{EMSA study}

Nuclear extracts of $\mathrm{CHO}$ cells were incubated in the presence of ERE/Spl-labeled oligonucleotide to prove if this region was able to bind ER $\alpha$ and/or Spl proteins. Nuclear proteins from CHO cells revealed the presence of a single band (Fig. 6, lane 1), which was inhibited by a 100-fold molar excess of the homologous ERE/Sp1 cold competitor (Fig. 6, lane 2), but remained substantially unchanged in the presence of the cold mutated competitor (Fig. 6, lane 3). The results showed an enhanced binding of the nuclear extracts, obtained from CHO cells over-expressing ER $\alpha$, to the ERE/Spllabeled oligonucleotide (Fig. 6, lane 5) and particularly evident upon $\mathrm{E}_{2}$ treatment (Fig. 6, lane 8). Both bands were abrogated by a 100 -fold molar excess of the cold 
competitor (Fig. 6, lanes 6 and 9). The specificity of the binding was demonstrated by immunodepletion induced by ER $\alpha$ and Spl antibodies (Fig. 6, lanes 10 and 11).

Using a labeled $\mathrm{Sp} 1$ oligonucleotide containing a GC box motif present in the Spl-rich region of the IRS-1 mouse promoter (from nt -490 to nt -455 ), in a cell-free system, ER $\alpha$ protein per se was unable to bind

A
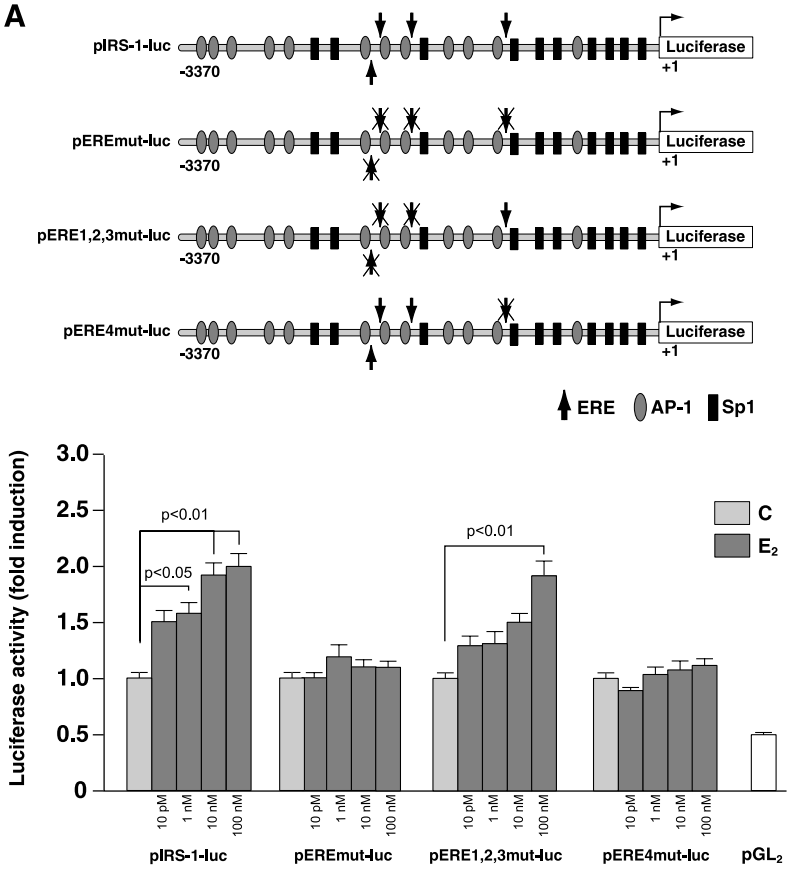

B

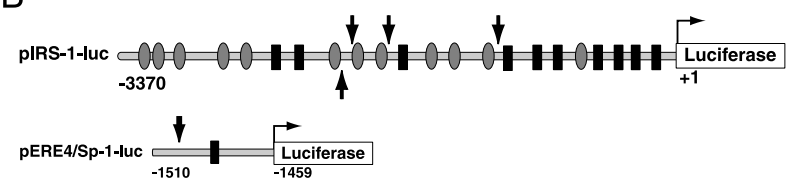

$+\quad+\quad$ A ERE OAP-1 |Sp1
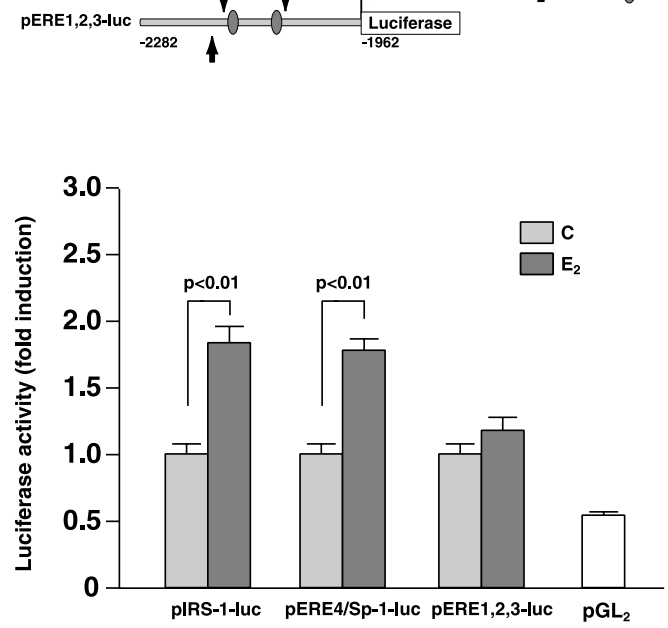

Journal of Molecular Endocrinology (2006) 36, 91-105 the Spl sequence (Fig. 7, lanes 1 and 2). However, the combined presence of $\mathrm{ER} \alpha$ at a lower concentration and Spl proteins resulted in a clearly enhanced Spl-DNA binding (Fig. 7, lanes 8 and 9) with respect to the one observed with Spl protein alone (Fig. 7, lanes 6 and 7). Spl protein was able to up-regulate its binding to the ERE/Spl sequence in a dose-related manner (Fig. 7, lanes 6 and 7). Such an up-regulatory effect produced by $\mathrm{ER} \alpha$ was drastically attenuated in the presence of cold ERE oligonucleotide (Fig. 7, lanes 10 and 11). On performing a new set of experiments using the same ERE/Spl-labeled oligonucleotide, as mentioned, it emerged that both $\mathrm{Spl}$ and $\mathrm{ER} \alpha$ were able to bind this sequence (Fig. 8A, lanes 1 and 4). Both bindings were abrogated by a 100 -fold molar excess of cold competitor (Fig. 8A, lanes 2 and 5) and restored in the presence of a mutated cold competitor (Fig. 8A, lanes 3 and 6). The specificity of the separate binding of the two proteins to the ERE/Spl sequence was demonstrated by the immunodepletion obtained in the presence of the two specific antibodies (Fig. 8A, lanes 8 and 9).

An increased amount of ER $\alpha$ enhanced $\mathrm{Sp} 1$ binding to the ERE/Sp1 sequence (Fig. 8B, lanes 6 and 7). In contrast, a progressive increase of Spl did not elicit any apparent influence on ER $\alpha$ binding (Fig. 8B, lanes 4 and $5)$. This up-regulatory effect was reversed by an excess of cold ERE oligonucleotide (Fig. 8B, lanes 8 and 9).

No cross-reaction was observed between the two specific antibodies (data not shown).

\section{$E R \alpha$ and Sp1 are recruited to the ERE/Sp1 sequences of the IRS-1 promoter in $\mathrm{CHO}$ cells}

The binding of ER $\alpha$ and Spl to the ERE/Spl-containing sequence of the IRS-1 gene promoter was confirmed by ChIP assays. CHO cells were transiently transfected with pHEGO and treated or not treated with $\mathrm{E}_{2}$ for $1 \mathrm{~h}$. The chromatin was immunoprecipitated with anti-ER $\alpha$ anti-

Figure 5 Identification of IRS-1 promoter region responsive to $\mathrm{E}_{2}$. (A) $\mathrm{CHO}$ cells were transiently co-transfected with pHEGO and with pIRS-1-luc or with pEREmut-luc, pERE4 mut-luc and pERE1,2,3 mut-luc, obtained by site-specific mutagenesis of IRS-1 promoter plasmid (see Materials and methods) together with $\mathrm{pRL}-\mathrm{TK}$. Cells were treated in the absence $(\mathrm{C}$, control) or in the presence of different doses of $E_{2}$ for $24 \mathrm{~h}$. (B) Transcriptional activity of $\mathrm{CHO}$ cells co-transfected with pHEGO and with pIRS-1-luc or pERE4/Sp1-luc or pERE1,2,3-luc luciferase reporter constructs (see Materials and methods) together with $\mathrm{pRL}-\mathrm{TK}$ are shown. Transfectants were treated in the absence $(\mathrm{C}$, control) or in the presence of $100 \mathrm{nM} \mathrm{E} \mathrm{E}_{2}$ for $24 \mathrm{~h}$. The results represent the means \pm S.D. of five different experiments assayed in triplicate transfections. $\mathrm{pGL}_{2}$ basal activity was measured in cells transfected with $\mathrm{pGL}_{2}$ basal vector. The firefly luciferase data for each sample were normalized on the basis of the transfection efficiency measured by Renilla luciferase activity. 


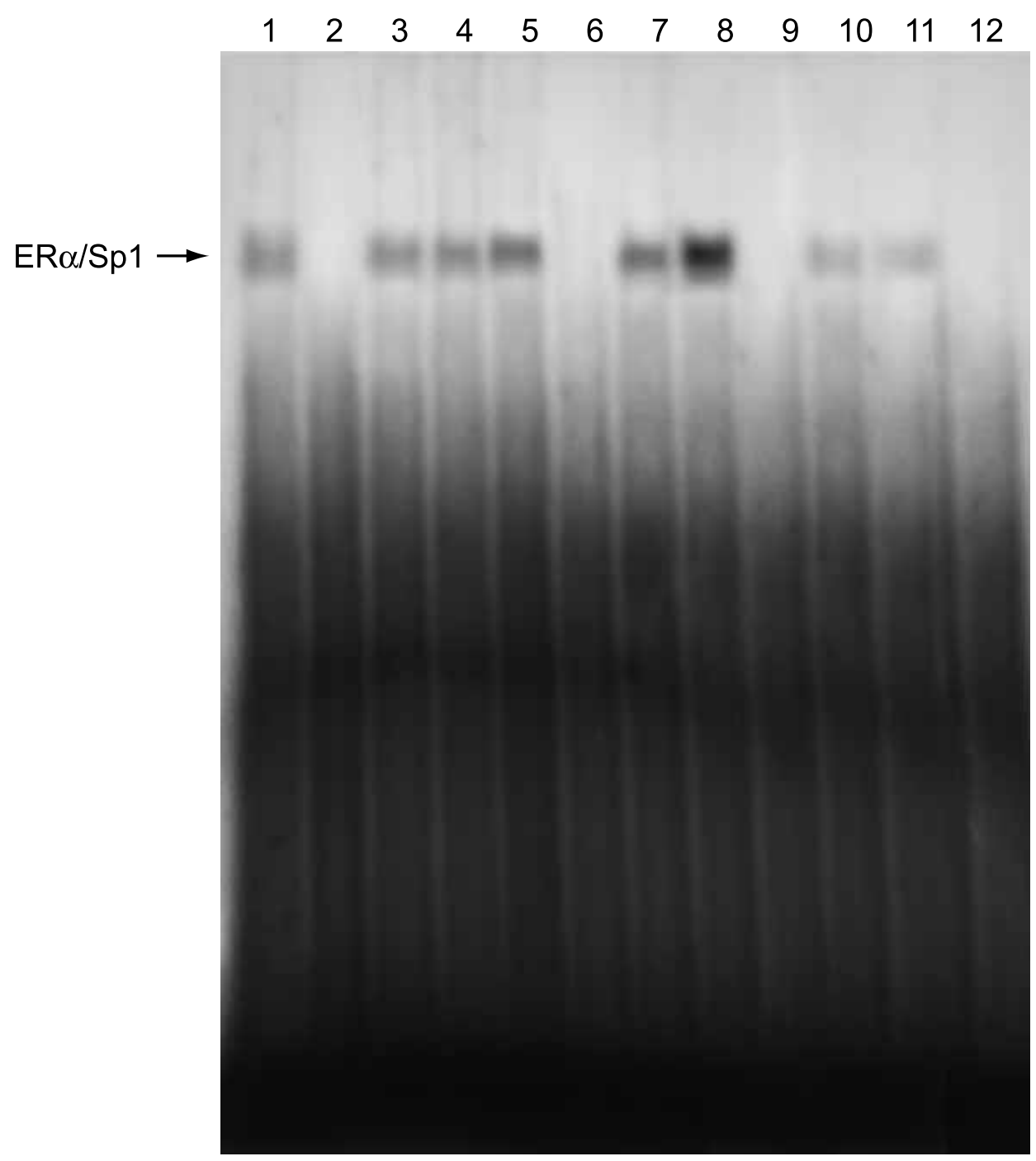

Nuclear extract $++++\mathrm{E}_{2}+\boldsymbol{+}+\mathrm{E}_{2}+\mathrm{E}_{2}+\mathrm{E}_{2} \quad+\mathrm{E}_{2} \quad-$

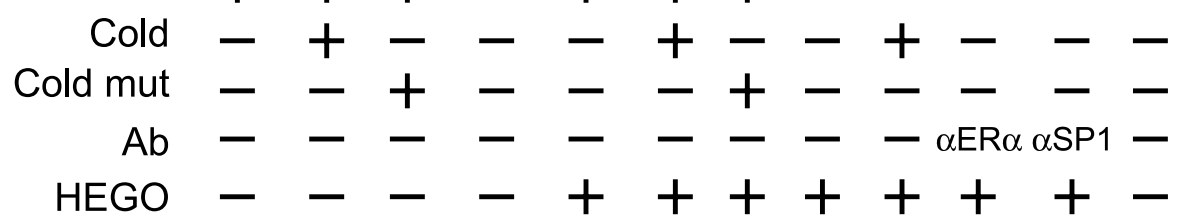

Figure 6 Binding of nuclear extracts from $\mathrm{CHO}$ cells and $\mathrm{CHO}$ cells transfected with pHEGO (CHO/HEGO) to ERE/Sp1 oligonucleotide. Nuclear extracts from CHO (lanes 1-4) and CHO/HEGO cells (lanes 5-11) were incubated with a double stranded ERE/Sp1 sequence probe labeled with [ $\gamma^{32}$ P]ATP and subject to electrophoresis in a $4 \%$ polyacrylamide gel. $\mathrm{CHO}$ and $\mathrm{CHO} / \mathrm{HEGO}$ nuclear extracts treated with $100 \mathrm{nM} \mathrm{E}_{2}$ for $24 \mathrm{~h}$ incubated with probe are shown in lanes 4 and 8 respectively. Competition experiments were performed by adding as competitor a 100 -fold molar excess of unlabeled ERE/Sp1 probe (lanes 2, 6 and 9) or a cold mutated (mut) competitor (lanes 3 and 7). The specificity of the binding was tested by adding to the reaction mixture an ER $\alpha$ antibody $(\alpha)$ (lane 10) or an Sp1 antibody ( $\alpha$ ) (lane 11). Lane 12 contains probe alone. The location of the $\mathrm{ER} \alpha / \mathrm{Sp} 1 / \mathrm{DNA}(\mathrm{ER} \alpha / \mathrm{Sp} 1)$ complex is indicated by the arrow. 

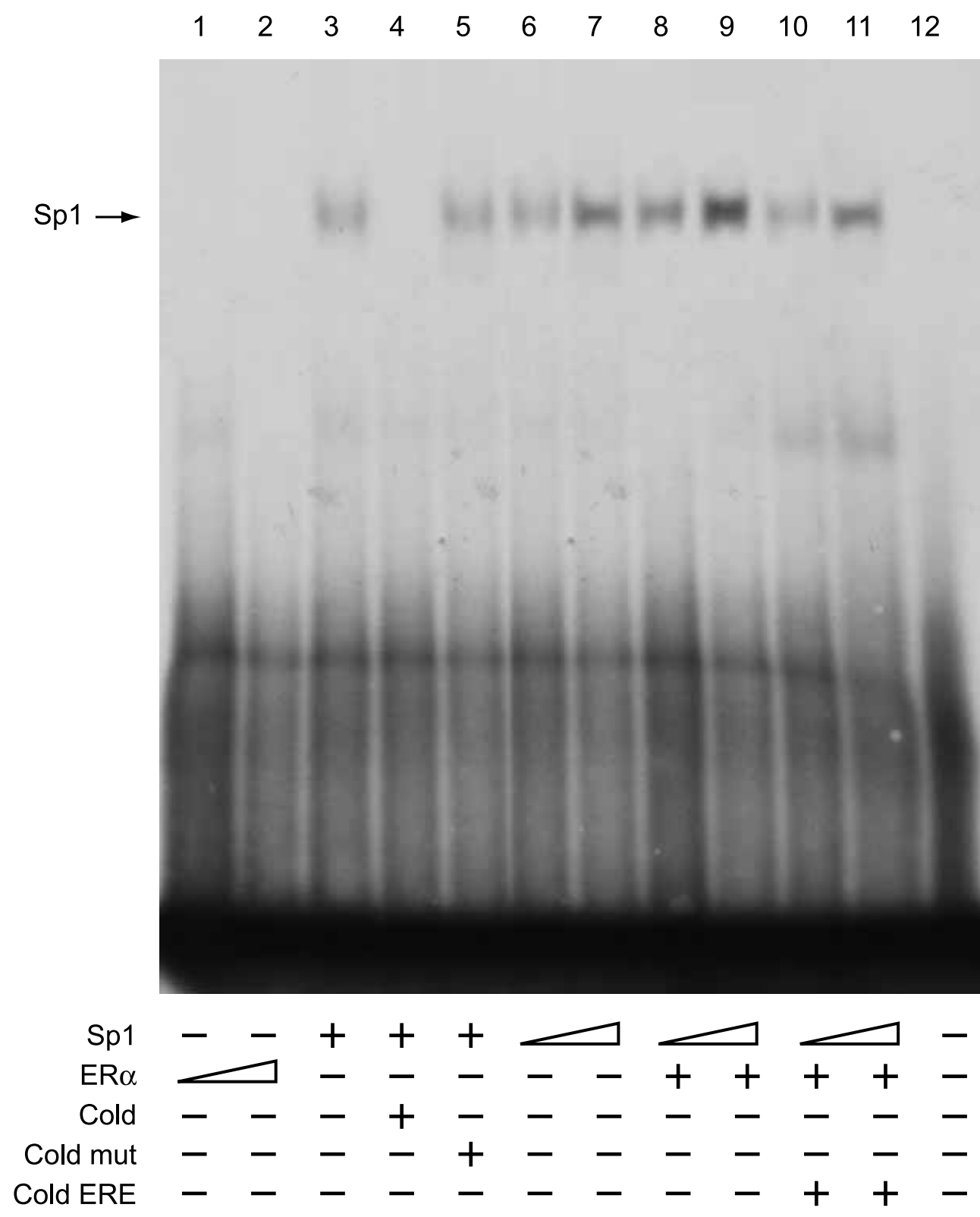

Figure 7 Binding of Sp1 to the Sp1 oligonucleotide in the presence of ER $\alpha .{ }^{32} \mathrm{P}$-labeled oligonucleotide containing the Sp1-binding site was incubated with: (i) $360 \mathrm{fmol}$ (lane 1) or $540 \mathrm{fmol}$ (lane 2) of $E R \alpha$ and (ii) $10 \mathrm{ng}$ (lanes 3 and 6) or $15 \mathrm{ng}$ (lane 7) of Sp1 and subjected to electrophoresis in a 4\% polyacrylamide gel. ER $\alpha(360 \mathrm{fmol})$ was incubated in the presence of $10 \mathrm{ng}$ (lane 8) or $15 \mathrm{ng}$ (lane 9) Sp1 protein. A competition experiment was performed by adding as competitor a 100 -fold molar excess of unlabeled probe (lane 4) or a cold mutated competitor (lane 5) or a cold ERE (lanes 10 and 11). Lane 12 contains probe alone. The location of the Sp1/DNA (Sp1) complex is indicated by the arrow.

body. Eluates from ER $\alpha$ IPs were re-immunoprecipitated with anti-Spl antibody (Re-ChIP) to confirm the co-existence of ER $\alpha / \mathrm{Spl}$ complex on the promoter (Fig. 9). The recovered DNA, opportunely amplified by using specific primers mapping the ERE/Spl-containing sequence, showed an increased occupancy of this region by the two proteins under $\mathrm{E}_{2}$ treatment (Fig. 9). No effect was observed when the amplified DNA region contained the other three non-functional ERE half sequences (data not shown). 
A

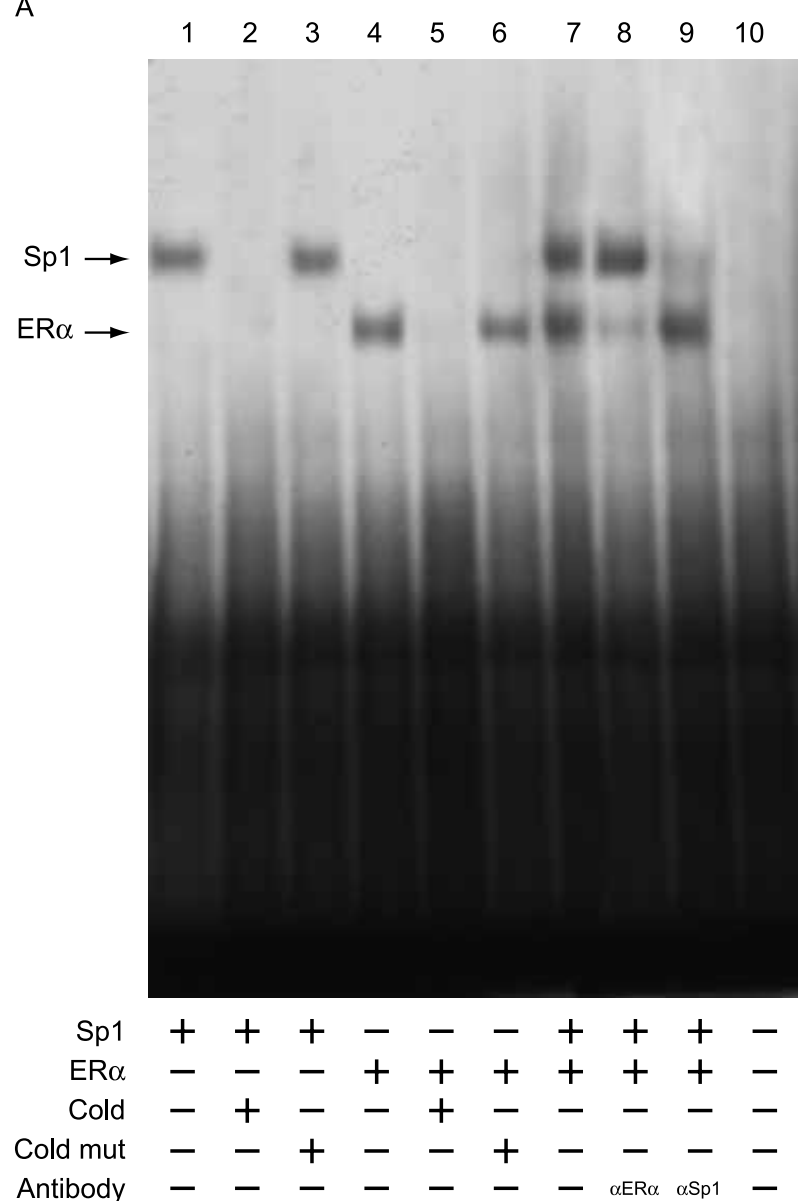

B

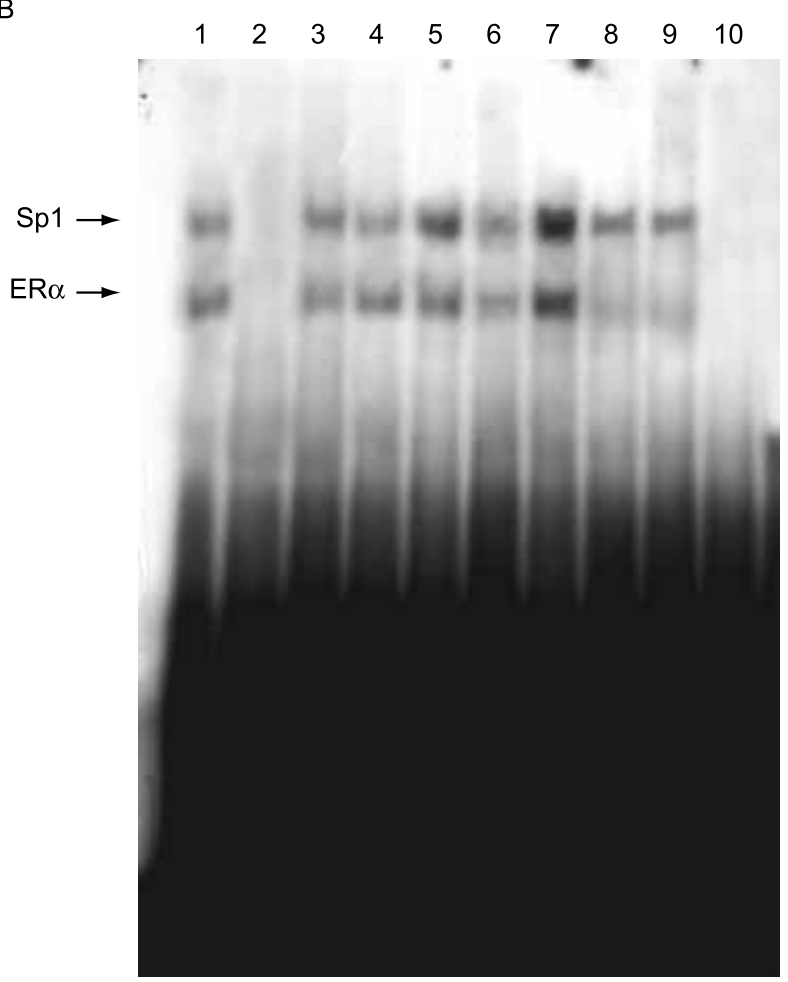

$$
\begin{aligned}
& \mathrm{Sp} 1+++\longleftarrow++++- \\
& \mathrm{ER} \alpha+++++\square- \\
& \text { Cold }-+------- \\
& \text { Cold mut }-\quad+\quad-\quad-\quad-\quad- \\
& \text { Cold ERE }--\quad-----++
\end{aligned}
$$

Figure 8 ER-enhanced binding of Sp1 to the half ERE/Sp1-binding site. (A) $10 \mathrm{ng} \mathrm{Sp} 1$ or 360 fmol ER $\alpha$ proteins were incubated with a double stranded ERE/Sp1 sequence probe labeled with [ $\left.\gamma^{32} \mathrm{P}\right] A T P$ and subject to electrophoresis in a $4 \%$ polyacrylamide gel (lanes 1 and 4 respectively). The specificity of the binding was proved by incubating the reaction mixture containing Sp1 and ER $\alpha$ proteins with an anti-Sp1 or anti-ER $\alpha$ antibodies (lanes 8 and 9 respectively). Competition experiments were performed by adding as competitor a 100-fold molar excess of unlabeled probe (lanes 2 and 5) or a cold mutated (mut) competitor (lanes 3 and 6). Lane 10 contains probe alone. The location of the Sp1/DNA (Sp1) and ER $\alpha$ /DNA (ER $\alpha$ ) complexes are indicated by the arrows. (B) ${ }^{32}$ P-labeled oligo containing the half ERE/Sp1-binding site was incubated with $10 \mathrm{ng}$ Sp1 and $360 \mathrm{fmol}$ ER $\alpha$ (lane 1) and subjected to electrophoresis in a $4 \%$ polyacrylamide gel. Competition experiments were performed by adding as competitor a 100 -fold molar excess of unlabeled probe (lanes 2) or a cold mutated (mut) competitor (lanes 3 ). Binding reaction contained 10 ng (lane 4) or $15 \mathrm{ng}$ (lane 5) Sp1 protein in combination with $360 \mathrm{fmol}$ ER $\alpha$ protein. Sp1 (10 ng) was incubated with $360 \mathrm{fmol}$ (lane 6) or $540 \mathrm{fmol}$ (lane 7) ER $\alpha$, in the absence (lanes 6 and 7) or presence (lanes 8 and 9) of cold ERE. Lane 10 contains probe alone. The location of the Sp1/DNA (Sp1) and ER $\alpha /$ DNA $(E R \alpha)$ complexes are indicated by the arrows.

\section{Discussion}

Our previous findings have shown how treatment of $\mathrm{CHO}$ cells and estrogen-responsive positive breast cancer cell lines with $\mathrm{E}_{2}$, for up to $24 \mathrm{~h}$, revealed an up-regulatory effect of $\mathrm{E}_{2}$ on the regulator region of the mouse IRS-1 gene (Mauro et al. 2001). We have here demonstrated that $\mathrm{E}_{2}$ at concentrations ranging from $10 \mathrm{pM}$ to $100 \mathrm{nM}$ produces the same up-regulatory effect on IRS-1 protein content in both $\mathrm{CHO}$ and human breast cancer MCF-7 cells. This suggests that there is a common regulatory mechanism controlling IRS-1 expression in the human and the mouse.

In order to investigate the molecular mechanism underlying the up-regulatory effect of $\mathrm{E}_{2}$ on the mouse IRS-1 promoter we used the same cell type where it had been first functionally characterized. With this aim, we transiently co-transfected $\mathrm{CHO}$ cells with the mouse IRS- 1 promoter and pHEGO and tested the response to different doses of $\mathrm{E}_{2}$ ranging from $10 \mathrm{pM}$ to $100 \mathrm{nM}$. The mouse IRS-1 gene, like other housekeeping genes, lacks the typical TATA and CAAT boxes (Araki et al. 


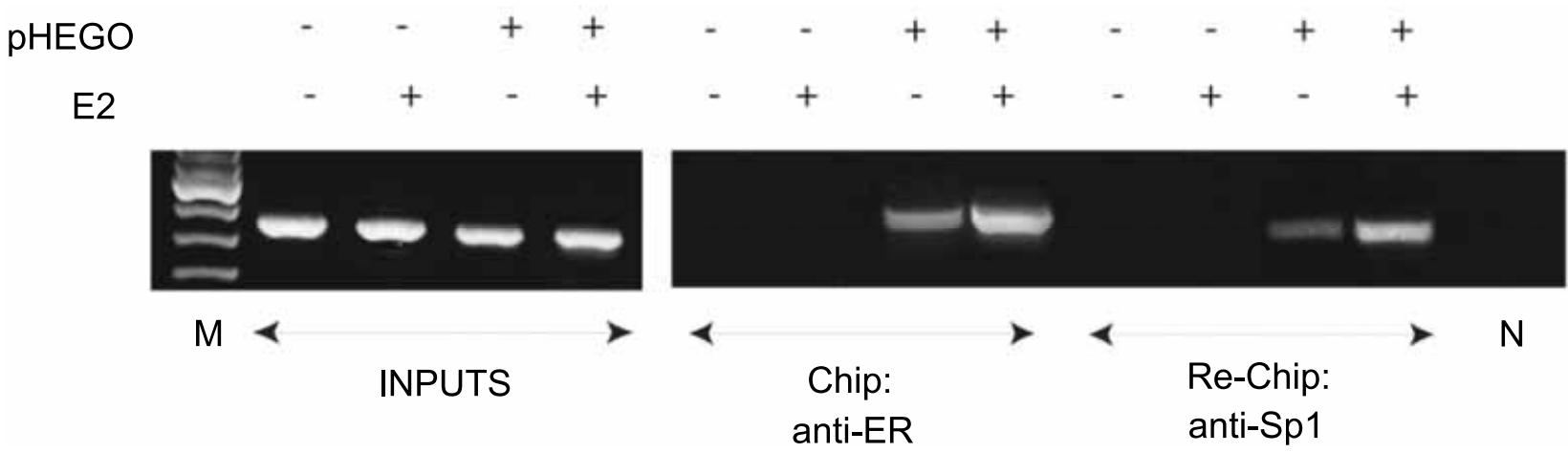

Figure 9 Recruitment of $\mathrm{ER} \alpha$ and Sp1 to the ERE/Sp1-containing IRS-1 promoter in $\mathrm{CHO}$ cells. CHO cells were transiently transfected with pHEGO and treated with $100 \mathrm{nM} \mathrm{E}_{2}$ for $1 \mathrm{~h}(+)$ or left untreated $(-)$. The cells were then cross-linked with formaldehyde, lysed and soluble, precleared chromatin was obtained as described in Materials and Methods. Chromatin (200 $\mu$ l) was immunoprecipitated with anti-ER $\alpha \mathrm{Ab}$ (Santa Cruz Biotechnology) (ChIP:anti-ER) and eluates from this IP were re-immunoprecipitated with anti-Sp1 Ab (Santa Cruz Biotechnology) (Re-ChIP: anti-Sp1). The immune complexes were reverse cross-linked, and DNA was recovered by phenol/chloroform extraction and Ethanol precipitation. IRS-1 promoter regions containing ERE/Sp1 sequences were detected in the recovered DNA by PCR amplification with specific primers (Materials and Methods). To determine input DNA, the IRS-1 promoter fragment was amplified from $5 \mu$ l purified soluble chromatin before immunoprecipitation. PCR products obtained at 35 cycles are shown. ChIP with non-immune IgG was used as negative control $(\mathrm{N}), \mathrm{M}=\mathrm{marker}$. This experiment was repeated three times with similar results.

1995) and contains thirteen AP-1- and ten Spl-binding sites and four ERE half sites.

It appears that in addition to binding to a classic ERE element, the ER may also modulate transcription indirectly by interaction with other DNA-binding proteins. Actually, ER interaction with AP-1-bound fos and jun proteins confers $\mathrm{E}_{2}$ responsiveness to the ovoalbumin (Gaub et al. 1990), c-fos (Weisz \& Rosales 1990), collagenase (Webb et al. 1992) and IGF-I (Umayahara et al. 1994) genes. However, previous studies have demonstrated ligand- and cell-context specific differences in ER $\alpha / A p 1$ and ER $\beta / A p 1$ action. For example, in HeLa cells both estrogens and anti-estrogens activated ER $\alpha / \mathrm{Apl}$, but only antiestrogens activated ER $\beta /$ Apl (Paech et al. 1997). Thus, the latter observation led us to investigate whether the region of the IRS-1 promoter rich in AP-1-binding sites was responsive to $\mathrm{E}_{2}$. Our results have shown that the $\mathrm{AP}-1$-rich region failed to be up-regulated by $\mathrm{E}_{2}$.

When we extended the molecular dissection downstream to implement the AP-1-rich region with the ERE half sites, the unresponsiveness to $\mathrm{E}_{2}$ was still persistent. In contrast, the remaining downstream region of the IRS-1 promoter rich in Spl-binding sites appears per se to be responsive to $\mathrm{E}_{2}$ stimulation.

EMSA studies, performed in a cell-free system, using an oligonucleotide reproducing the $\mathrm{Spl}$ sequence present in the mouse IRS-1 promoter, revealed how $\mathrm{ER} \alpha$ did not bind the Spl sequence but was able to enhance Spl binding to its own responsive element.

$\mathrm{Sp} 1$ was originally described as a trans-acting factor that bound to the GC box and activated transcription of the SV40 promoter (Dynan \& Tjian 1983, Gidoni et al.
1984). However, it has been subsequently identified as a higher affinity consensus Spl site 5'-GGGGCGG GGC-3' and it has been also discovered that the sequences that varied from this consensus sequence displayed decreased affinities for Spl (Briggs et al. 1986). It is worth noting how the GC-rich region, when present in the full length of the IRS-1 mouse promoter mutated for deletion in all four ERE half sites, loses its intrinsic $\mathrm{E}_{2}$ responsiveness. This led us to investigate the potential role of ERE half site as involved in IRS- $1 \mathrm{E}_{2}$ responsiveness, taking into account the ability of ER $\alpha$ to bind as a monomer to the consensus ERE half site (Wood et al. 1998). Among the different ERE half sites tested, only the ERE at the position nt -1500 to - 1495, appears to be crucial in conferring $\mathrm{E}_{2}$ responsiveness to the whole promoter. The latter ERE half site was the closest one to the $\mathrm{Spl}$ sequence nt -1482 to -1477 . Indeed, in CHO cells, only the construct bearing the ERE/Spl sequence has reproduced the same pattern of $\mathrm{E}_{2}$ responsiveness as that given by the full length IRS-1 promoter. Because of this we reasonably postulated a functional interaction between ERE half sites and the Spl-rich region downstream.

Results from the EMSA showed that the binding of the untreated nuclear extract to the labeled ERE/Spl oligonucleotide, bearing both ERE half site and Spl

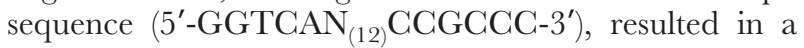
single band which was enhanced in the presence of ectopic ER $\alpha$ and drastically increased upon prolonged $\mathrm{E}_{2}$ exposure. In the latter condition, a clear immunodepletion occurred in the presence of either anti-Spl or anti-ER $\alpha$ antibodies. 
The ability of Spl and ER $\alpha$ to bind separately was demonstrated by two distinct bands which were abrogated in the presence of an excess of cold oligonucleotide and immunodepleted in the presence of an anti-ER $\alpha$ antibody in a cell-free system.

Progressively increased amounts of purified ER $\alpha$ protein enhanced Spl binding to the half ERE/Sp1binding site in a dose-dependent manner, while increased amounts of $\mathrm{Spl}$ were unable to do so.

All these data have demonstrated that ER $\alpha$ enhances Spl binding and that both $\mathrm{ER} \alpha$ and $\mathrm{Spl}$ can bind directly to the half ERE/Spl-binding site. On the other hand, the binding of ER $\alpha$ and Spl to the ERE/Sp1containing sequence of the IRS-1 gene promoter was confirmed by ChIP assay which showed an increased occupancy of this region by the two proteins under $\mathrm{E}_{2}$ treatment. In contrast, this was not observed when, in the ChIP assay, we used the sequence containing the first three ERE half sites. On the basis of these findings, it emerges that the ERE/Spl-binding site is crucially involved in mediating $\mathrm{E}_{2}$ responsiveness to the IRS-1 gene. In contrast, the three non-functional ERE half sequences upstream of the ERE/Spl site are not involved in the process. This finding acquired relevance when we became aware of how the functional synergism between Spl and ER $\alpha$, through the formation of the $\mathrm{ER} \alpha / \mathrm{Sp} 1$ complex, was responsible of the activation of other $\mathrm{E}_{2}$-responsive genes. For instance, in the promoter region of such genes the half palindromic ERE sequence and Spl were separated by a number of nucleotides ranging from 10 to $23 \mathrm{nt}$, such as cyclin D1, bcl2, retinoic acid receptor $\alpha 1$, IGF-binding protein 4 , adenosine deaminase, DNA polymerase $\alpha, c-f o s$, cathepsin $\mathrm{D}$, transcription factor-E2F1, creatine kinase B, human progesterone receptor A promoter and, recently, cad gene (Dubik \& Shiu 1992, Wu-Peng et al. 1992, Krishnan et al. 1994, Rishi et al. 1995, Porter et al. 1996, 1997, Scholz et al. 1998, Wang et al. 1998, Petz \& Nardulli 2000, Salvatori et al. 2000, Saville et al. 2000, Tanaka et al. 2000, Vyhlidal et al. 2000, Li et al. 2001, Khan et al. 2003).

While models of DNA are typically drawn in a linear array, the packaging of DNA and proteins into the nucleus of a cell requires tremendous compaction. This compaction could facilitate interaction between transacting factors bound to more distant cis elements. For instance, both ER $\alpha$ and SP1 are known to directly associate with the Transcription Factor (TFII) component. In particular, Spl has been reported to recruit TFII/TFII-binding protein and mediate formation of the transcription preinitiation complex on the TATAless promoter (Pugh \& Tjian 1991).

On the other hand, ER $\alpha$ as is known, interacts with the TATA-binding protein (TBP) transcription factor IIb (TFIIb) and TBP-associated factor (TAF) II $^{30}$ (Ing et al. 1992, Jacq et al. 1994, Sabbah et al. 1998)). Thus, we can reasonably assume that the interaction of $\mathrm{ER} \alpha$ and SP1, by recruiting TFII/TFII-binding protein, could foster the formation of a protein-protein network that helps to establish an active transcriptional complex. Furthermore, the $\mathrm{E}_{2}$-dependent recruitment of coactivators such as CREB binding protein (CBP)/p300, which can function as a histone acetyltransferase (Ogryzko et al. 1996), could help remodel chromatin in different promoters and enhance formation of an interconnected protein-protein and protein-DNA network involved in activation of the IRS-1 gene.

Thus, the active complex ER $\alpha / \mathrm{E}_{2}-\mathrm{Sp} 1$ could trigger the interaction between trans-acting factors bound to more distant cis elements, like the GG downstream elements, potentiating the transcriptional machinery at the level of the whole GG-rich region of the IRS-1 promoter, which is a region reported to have positive active elements on IRS-1 promoter activity (Araki et al. 1995).

Thus, with the present findings, we have demonstrated the molecular mechanism through which $\mathrm{E}_{2} / \mathrm{ER} \alpha$ up-regulates mouse IRS-1 expression, thereby amplifying IGF-I/insulin signaling.

Since IRS-1 is sufficient to increase rRNA synthesis and cell size (Sun et al. 2003), its enhanced expression, upon prolonged $\mathrm{E}_{2}$ exposure, may establish another intriguing link between $\mathrm{E}_{2}$, cell growth and its mitogenic potentiality.

\section{Acknowledgements}

We thank Dr Domenico Sturino for the English revision of the manuscript and Dr Pasquale Cicirelli for technical assistance. This work was supported by A.I.R.C. grant 2003. The authors declare that there is no conflict of interest that would prejudice the impartiality of this scientific work.

\section{References}

Ando' S, Panno ML, Salerno M, Sisci D, Mauro L, Lanzino M \& Surmacz E 1998 Role of IRS-1 signaling in insulin-induced modulation of estrogen receptors in breast cancer cells. Biochemical and Biophysical Research Communication 253 315-319.

Andrews NC \& Faller DV 1991 A rapid micropreparation technique for extraction of DNA-binding proteins from limiting numbers of mammalian cells. Nucleic Acids Research 192499.

Araki E, Haag BL, Matsuda K, Shichiri M \& Kahn R 1995 Characterisation and regulation of the mouse insulin receptor substrate gene promoter. Molecular Endocrinology 9 1367-1379.

Ausubel FM, Brent R, Kingston RE, Moore DD, SeidmanJD \& Struhl K 1988 Enzymatic manipulation of DNA and RNA. In Current Protocols in Molecular Biology, vol.1. pp 3.0.1-3.17.3 Hoboken, NJ: John Wiley \& Sons Inc.

Briggs MR, Kadonaga JT, Bell SP \& Tjian R 1986 Purification and biochemical characterization of the promoter-specific transcription factor, Spl. Science 234 47-52. 
Clackson T, Gussow D \& Jones PT 1991 General application of PCR to gene cloning and manipulation. In PCR. A Pratical Approach. pp 185-192. Eds MJ McPherson, P Quirke \& GR Taylor. New York: Oxford University Press.

Dickson RB \& Lippman ME 1987 Estrogenic regulation of growth factor secretion in human breast carcinoma. Endocrine Reviews 8 $29-43$.

Dickson RB \& Lippman ME 1995 Growth factors in breast cancer. Endocrine Reviews 16 559-589.

Dubik D \& Shiu R 1992 Mechanism of estrogen activation of c-myc oncogene expression. Oncogene 7 1587-1594.

Dynan WS \& Tjian R 1983 The promoter-specific transcription factor Spl binds to upstream sequences in the SV40 early promoter. Cell 35 79-87.

Gaub MP, Bellard M, Scheuer I, Chambon P \& Sassone-Corsi P 1990 Activation of the ovalbumin gene by the estrogen receptor involves the Fos-Jun complex. Cell 63 1267-1276.

Gidoni D, Dynan WS \& Tjian R 1984 Multiple specific contacts between a mammalian transcription factor and its cognate promoters. Nature 312 409-413.

Guvakova MA \& Surmacz E 1997 Overexpressed IGF-I receptors reduce estrogen growth requirements, enhance survival, and promote E-cadherin-mediated cell-cell adhesion in human breast cancer cells. Experimental Cell Research 231 149-162.

Ing NH, Beekman JM, Tsai SY, Tsai MJ \& O’Malley BW 1992 Members of the steroid hormone receptor superfamily interact with TFIIB (S300-II). Fournal of Biological Chemistry 267 17617-17623.

Jacq X, Brou C, Lutz Y, Davidson I, Chambon P \& Tora L 1994 Human TAFII30 is present in a distinct TFIID complex and is required for transcriptional activation by the estrogen receptor. Cell 79 107-117.

Khan S, Abdelrahim M, Samudio I \& Safe S 2003 Estrogen receptor/Spl complexes are required for induction of cad gene expression by 17 beta-estradiol in breast cancer cells. Endocrinology $1442325-2335$.

Krishnan V, Wang X \& Safe S 1994 Estrogen receptor-Sp1 complexes mediate estrogen-induced cathepsin D gene expression in MCF-7 human breast cancer cells. Fournal of Biological Chemistry $26915912-15917$.

Lee AV, Jackson JG, Gooch JL, Hilsenbeck SG, Coronado-Heinsohn E, Osborne GK \& Yee D 1999 Enhancement of insulin-like growth factor signaling in human breast cancer: estrogen regulation of insulin receptor substrate-1 expression in vitro and in vivo. Molecular Endocrinology 13 787-796.

Li C, Briggs MR, Ahlborn TE, Kraemer FB \& Liu J 2001 Requirement of $\mathrm{Spl}$ and estrogen receptor alpha interaction in 17 beta-estradiol-mediated transcriptional activation of the low density lipoprotein receptor gene expression. Endocrinology 142 $1546-1553$

Mauro L, Salerno M, Panno ML, Bellizzi D, Sisci D, Miglietta A, Surmacz E \& Ando' S 2001 Estradiol increases IRS-1 gene expression and insulin signaling in breast cancer cells. Biochemical and Biophysical Research Communication 288 685-689.

Molloy CA, May FEB \& Westley BR 2000 Insulin receptor substrate-1 expression regulated by estrogen in the MCF-7 human breast cancer cell line. Fournal of Biological Chemistry 275 12565-12571.

Morelli C, Garofalo C, Sisci D, del Roncon S, Cascio S, Tu X, Vecchione A, Sauter ER, Miller WH Jr \& Surmacz E 2004 Nuclear insulin receptor substrate 1 interacts with estrogen receptor alpha at ERE promoters. Oncogene 23 7517-7526.

Ogryzko VV, Schiltz RL, Russanova V, Howard BH \& Nakatani Y 1996 The transcriptional coactivators p300 and CBP are histone acetyltransferases. Cell 87 953-959.

Paech K, Webb P, Kuiper GG, Nilsson S, Gustafsson JA, Kushner PJ \& Scanlan TS 1997 Differential ligand activation of estrogen receptors ERalpha and ERbeta at AP1 sites. Science $\mathbf{2 7 7}$ $1508-1510$
Petz LN \& Nardulli AM 2000 Spl binding sites and an estrogen response element half-site are involved in regulation of the human progesterone receptor A promoter. Molecular Endocrinology 14 972-985.

Porter W, Wang F,Wang W, Duan R \& Safe S 1996 Role of estrogen receptor/Spl complexes in estrogen-induced heat shock protein 27 gene expression. Molecular Endocrinology 10 1371-1378.

Porter W, Saville B, Hoivik D \& Safe S 1997 Functional synergy between the transcription factor $\mathrm{Spl}$ and the estrogen receptor. Molecular Endocrinology 11 1569-1580.

Pugh BF \& Tjian R 1991 Transcription from a TATA-less promoter requires a multisubunit TFIID complex. Genes and Development 5 $1935-1945$.

Quandt K, Frech K, Karas H, Wingender E \& Werner T 1995 MatInd and MatInspector: new fast and versatile tools for detection of consensus matches in nucleotide sequence data. Nucleic Acids Research 23 4878-4884.

Rishi A, Hhao ZM, Baumann R, Li XS, Sheikh S, Kimura S, Bashirelahi N \& Fontana J 1995 Estradiol regulation of the human retinoic acid receptor gene in human breast carcinoma cells is mediated via an imperfect half-palindromin estrogen response element and Spl motifs. Cancer Research 55 4999-5006.

Sabbah M, Kang KI, Tora L \& Redeuilh G 1998 Oestrogen receptor facilitates the formation of preinitiation complex assembly: involvement of the general transcription factor TFIIB Biochemical fournal 336 639-646.

Salvatori L, Ravenna L, Felli MP, Cardillo MR, Russo MA, Frati L, Gulino A \& Petrangeli E 2000 Identification of an estrogen-mediated deoxyribonucleic acid-binding independent transactivation pathway on the epidermal growth factor receptor gene promoter. Endocrinology 141 2266-2274.

Saville B, Wormke M, Wang F, Nguyen T, Enmark E, Kuiper G, Gustafsson JA \& Safe S 2000 Ligand-, cell-, and estrogen receptor subtype (alpha/beta)-dependent activation at GC-rich (Spl) promoter elements. Fournal of Biological Chemistry 275 5379-5387.

Scholz A, Truss M \& Beato M 1998 Hormone-induced recruitment of $\mathrm{Sp}-1$ mediates estrogen activation of the rabbit uteroglobin gene in endometrial epithelium. Fournal of Biological Chemistry 273 $4360-4366$

Sun H, Tu X, Prisco M, Wu A, Casaburi I \& Baserga R 2003 Insulin-like growth factor receptor signaling and nuclear translocation of insulin receptor substrates 1 and 2. Molecular Endocrinology 17 472-486.

Surmacz E 2000 Function of the IGF-IR in breast cancer. Fournal of Mammary Gland Biology and Neoplasia 5 95-105.

Tanaka N, Yonekura H, Yamagishi S, Fujimori H, Yamamoto Y \& Yamamoto H 2000 The receptor for advanced glycation end products is induced by the glycation products themselves and tumor necrosis factor-alpha through nuclear factor-kappa B, and by 17 beta-estradiol through $\mathrm{Sp}-1$ in human vascular endothelial cells. Fournal of Biological Chemistry 275 25781-25790.

Umayahara Y, Kawamori H, Watada H, Imano E, Iwama N, Morishima T, Yamasaki Y, Kajimoto Y \& Kamada T 1994 Estrogen regulation of the insulin-like growth factor I gene transcription involves an AP-1 enhancer. Fournal of Biological Chemistry 269 16433-16442.

Vyhlidal C, Samudio I, Kladde MP \& Safe S 2000 Transcriptional activation of transforming growth factor alpha by estradiol: requirement for both a GC-rich site and an estrogen response element half-site. Fournal of Molecular Endocrinology 24 329-338.

Wang F, Hoivik D, Pollenz R \& Safe S 1998 Functional and physical interactions between the estrogen receptor $\mathrm{Spl}$ and nuclear arcyl hydrocarbon receptor complexes. Nucleic Acid Research $263044-3052$.

Webb P, Lopez GN, Greene GL, Baxter JD \& Kushner PJ 1992

The limits of the cellular capacity to mediate an estrogen response. Molecular Endocrinology 6 157-167. 
Webb P, Nguyen P, Valentine C, Lopez GN, Kwok GR, McInerney E, Katzenellenbogen BS, Enmark E, Gustafsson JA, Nilsson S \& Kushner PJ 1999 The estrogen receptor enhances AP-1 activity by two distinct mechanisms with different requirements for receptor transactivation functions. Molecular Endocrinology 13 1672-1685.

Weisz A \& Rosales R 1990 Identification of an estrogen response element upstream of the human $c$-fos gene that binds the estrogen receptor and the AP-1 transcription factor. Nucleic Acids Research 18 5097-5106.

Wood JR, Greene GL \& Nardulli AM 1998 Estrogen response elements function as allosteric modulators of estrogen receptor conformation. Molecular and Cellular Endocrinology 18 1927-1934.
Wu-Peng X, Pugliese T, Dickerman H \& Pentecost B 1992 Delineation of sites mediating estrogen regulation of the rat creatine kinase B gene. Molecular Endocrinology 6 231-240.

Yee D \& Lee AV 2000 Crosstalk between the insulin-like growth factor and estrogens in breast cancer. Fournal of Mammary Gland Biology and Neoplasia 5 1-5.

Received in final form 21 October 2005

Accepted 26 October 2005

Made available online as an Accepted Preprint 18 November 2005 